\title{
DESAIN KRITERIA PEMILIHAN PENYEDIA JASA KONSTRUKSI BANGUNAN MENGGUNAKAN METODE EVALUASI DENGAN MERIT POINT SYSTEM
}

\author{
Nia Budi Puspitasari*), Dyah Ika Rinawati, Aditya Wiratama Putra \\ Departemen Teknik Industri, Fakultas Teknik, Universitas Diponegoro, \\ Jl. Prof. Soedarto, SH, Semarang, Indonesia 50275
}

(Received: January 30, 2018/ Accepted: May 31, 2018)

\begin{abstract}
Abstrak
Dalam melakukan proses pengadaan, Badan Usaha Milik Negara mengacu pada peraturan Menteri BUMN No. 05 tahun 2008. Dimana tertulis dalam peraturan menteri bahwa tata cara pengadaan barang dan jasa diatur lebih lanjut oleh direksi BUMN. PT Asuransi ASEI Indonesia sebagai BUMN mempunyai keputusan direksi No : 01/045-2/SKD.KN.HKM sebagai landasan segala proses pengadaan. Salah satu bentuk evaluasi lelang adalah merit point system. Sistem yang digunakan untuk memilih penyedia jasa konstruksi pembangunan gedung di PT. Asuransi ASEI Indonesia adalah sistem design \& build procurement. Namun PT. Asuransi ASEI Indonesia masih sulit untuk melakukan penilaian terhadap penyedia yang mengikuti proses lelang terbuka. Hal ini dibuktikan dengan merit point system yang diatur dalam keputusan direksi PT. Asuransi ASEI Indonesia belum memiliki sub-kriteria dan bobot untuk mengukur kriteria. Akibatnya merit point system dapat melahirkan penyedia dengan kinerja yang buruk. Seperti yang dialami oleh PT. Asuransi ASEI Indonesia bahwa pembangunan gedung kantor cabang di Surabaya tahun 2015 sedang terhenti akibat kesalahan penyedia. Untuk mengatasi masalah tersebut, maka penelitian menggunakan tools Fuzzy Analytical Hierarchy Process untuk menentukan kriteria, sub-kriteria, dan bobot sebagai bahan masukan untuk menyempurnakan merit point system. Hasil Pengolahan data menunjukan bahwa kriteria structural system merupakan kriteria yang paling penting untuk memilih penyedia dengan bobot sebesar 19,7\%.
\end{abstract}

Kata kunci: Pengadaan; Merit Point System; Fuzzy Analytical Hierarchy Process

\begin{abstract}
In the process of procurement, the state owned enteprises (BUMN) refer to minister regulation no 5 of 2008. Which is stated on the minister regulation that the procedure of procurement is further regulated by the regulation of the state owned enterprises itself. PT Asuransi ASEI Indonesia as one of the state owned enteprises has a director regulation no 01/0452/SKD.KN.HKM as the foundation all of procurement process on PT. Asuransi ASEI Indonesia. One of the tender evaluations which is stated on the director regulation is by merit point system. The system that used for selecting provider on the tender evaluation is by design \& build procurement. But PT. Asuransi ASEI Indonesia have some problem for evaluating provider who join the tender. This is proved by merit point system that regulated on the regulation of PT. Asuransi ASEI Indonesia doesn't have criteria and weight for measure the criteria. So, merit point system can provide some provider with a bad performance for doing the project.As experienced by PT. Asuransi ASEI Indonesia that the construction process of the Surabaya branch office has been stopped (2015) because of provider's failure. For solving the problem, this research using tools Fuzzy Analytical Hierarchy Process for determining criteria, subcriteria, and the weight as advice for complementing merit point system. The result show that structural system is the most important criteria for choosing the provide with the criteria weight of $19,7 \%$.
\end{abstract}

Keywords: Procurement; Merit Point System; Fuzzy Analytical Hierarchy Process

\footnotetext{
*) Penulis Korespondensi.

e-mail: niabudipuspitasari@gmail.com
} 


\section{Pendahuluan}

PT. Asuransi Ekspor Indonesia (Persero) adalah Badan Usaha Milik Negara (BUMN) yang berdiri tahun 1985, dan tahun 2014 bertransformasi menjadi PT. Asei Reasuransi Indonesia (Persero). Asuransi Asei menyediakan rangkaian produk yang terintegrasi melalui produk-produk unggulannya yakni Asuransi Ekspor, Asuransi Kredit, Asuransi Umum, dan Penjaminan dan Asuransi Syariah.

Saat ini, Asuransi ASEI tumbuh dan berkembang menjadi perusahaan asuransi terkemuka di Indonesia dan telah memiliki 21 kantor cabang dan 30 kantor pemasaran yang tersebar di seluruh Indonesia dan terus meningkat jumlahnya. Penambahan jumlah gedung di beberapa daerah strategis adalah prioritas utama PT. Asuransi ASEI Indonesia untuk memberikan pelayanan terbaik bagi nasabah di seluruh Indonesia. Hal ini dibuktikan dengan meningkatnya alokasi belanja modal gedung kantor PT. Asuransi ASEI Indonesia dalam 5 tahun terakhir seperti dalam Gambar 1.

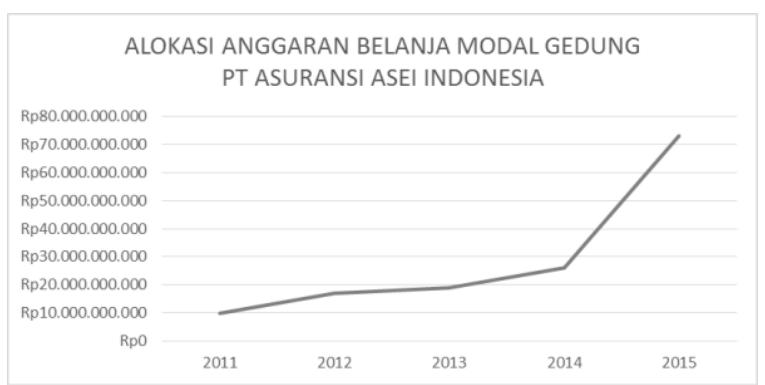

Gambar 1. Alokasi Anggaran Belanja Modal Gedung PT. Asuransi ASEI Indonesia

Dalam melakukan pengadaan atau public procurement, PT. Asuransi ASEI Indonesia sebagai Badan Usaha Milik Negara mengacu pada Peraturan Menteri Negara Badan Usaha Milik Negara Nomor 05 Tahun 2008 tentang Pedoman Umum Pelaksanaan Pengadaan Barang Dan Jasa Badan Usaha Milik Negara. Dimana tata cara pengadaan barang dan jasa diatur lebih lanjut oleh direksi BUMN. Selanjutnya PT. Asuransi ASEI Indonesia memiliki Keputusan Direksi PT Asuransi ASEI Indonesia Nomor : 01/045-2/SKD.KN.HKM Tentang Pedoman Pengadaan Barang dan Jasa yang mengatur seluruh pengadaan di PT. Asuransi ASEI Indonesia.

Pengadaan barang dan jasa PT. Asuransi ASEI Indonesia dengan nilai pengadaan lebih dari $\mathrm{Rp}$ 1.000.000.000 (satu milyar rupiah) dilakukan dengan metode lelang terbuka. Evaluasi lelang terbuka dapat dilaksanakan dengan cara merit point system, yaitu dengan cara memberikan bobot dan nilai pada setiap unsur yang dinilai.

Berdasarkan studi pendahuluan yang dilakukan dengan Kepala Divisi Sumber Daya Manusia dan Umum PT. Asuransi ASEI Indonesia pada tahun 2015, Sistem yang digunakan untuk memilih penyedia jasa konstruksi pembangunan gedung di
PT. Asuransi ASEI Indonesia adalah sistem design \& build procurement yang berarti setiap penyedia yang ingin mengikuti lelang terbuka proyek pembangunan gedung PT. Asuransi ASEI Indonesia harus mendesain sendiri secara keseluruhan proyek tersebut. Dimana alternatif desain setiap penyedia akan dinilai oleh Pejabat Pelaksana Pengadaan Barang dan Jasa (PPBJ) PT. Asuransi ASEI Indonesia.

Karena menggunakan sistem design \& build procurement, PT. Asuransi ASEI Indonesia masih sulit untuk melakukan penilaian terhadap penyedia yang mengikuti proses lelang terbuka. Hal ini disebabkan kriteria yang ada dalam keputusan direksi dianggap masih belum mampu digunakan untuk memilih penyedia dengan sistem design \& build procurement. Hal ini dibuktikan dengan merit point system yang diatur dalam keputusan direksi PT. Asuransi ASEI Indonesia belum memiliki subkriteria untuk mengukur kriteria, juga belum memiliki bobot masing masing kriteria penilaian. Akibatnya merit point system dapat melahirkan penyedia dengan kualitas yang tidak sesuai dengan standar dan kinerja yang buruk dalam melaksanakan proyek. Hal ini dialami oleh PT. Asuransi ASEI Indonesia, dimana proyek pembangunan gedung kantor cabang Surabaya pada tahun 2015 sedang dihentikan karena penyedia tidak bekerja sesuai dengan rencana yang ada. Hal ini akan menyebabkan waktu selesai proyek otomatis mundur dan dapat menyebabkan kerugian pada operasional perusahaan sendiri.

Untuk menyelesaikan masalah tersebut, penulis mengajukan penelitian yang berguna sebagai alat teknik untuk menentukan kriteria dan sub-kriteria dalam memilih penyedia menggunakan tools Fuzzy Analytical Hierarchy Process. Dimana output dari tools ini berupa bobot masing-masing kriteria dan sub-kriteria. Besar bobot ini sangat penting karena diukur berdasarkan tingkat kepentingan masingmasing kriteria dan sub-kriteria berdasarkan masukan dari pejabat di PT. Asuransi ASEI Indonesia. Sehingga saat mengevaluasi dokumen lelang terbuka menggunakan merit point system, pemberian nilai bobot dilakukan berdasarkan tingkat kepentingan kriteria dan sub-kriteria yang diinginkan. Dimana kriteria dan sub-kriteria yang semakin penting akan menghasilkan bobot yang paling besar. Sehingga diharapkan penyedia yang lahir dari merit point system adalah benar-benar penyedia yang berkompeten dan mampu memenuhi kriteria PT.n Asuransi ASEI Indonesia.

\section{Bahan dan Metode \\ Pengadaan}

Definisi pengadaan menurut Departement of Trade and Industry (2003) adalah pengadaan barang atau jasa. Procurement dilakukan oleh suatu organisasi untuk memenuhi kontrak dalam mengembangkan public service. Setiap perusahaan 
menggunakan metode yang berbeda dalam memperoleh produk dan jasa yang tergantung apa dan dimana mereka membeli, kuantitas yang diperlukan, berapa jumlah uang yang terpakai, dan sebagainya. Metode procurement antara lain :

- Membeli dari manufaktur, penjual grosir atau pengecer dari katalog-katalog mereka dan adanya negoisasi

- Membeli melalui katalog yang terhubung dengan memeriksa katalog penjual atau membeli melalui mal-mal industri

- Membeli melalui katalog pembeli internal dimana perusahaan menyetujui katalogkatalog vendor termasuk kesepakatan harga

- Mengadakan penawaran tender dari sistem dimana pemasok bersaing dengan yang lainnya. Metode ini digunakan untuk pembelian dalam jumlah besar.

- Membeli dari situs pelelangan dimana organisasi berpartisipasi sebagai salah satu pembeli

- Bergabung dengan suatu kelompok sistem pembeli dimana memeriksa permintaan partisipasi, menciptakan jumlah besar, kemudian kelompok ini dapat menegoisasikan harga

- Berkolaborasi dengan pemasok untuk berbagi informasi tentang penjualan dan persediaan, sehingga dapat mengurangi persediaan, stockout dan mempertinggi ketepatan pengiriman.

\section{Proses Tender}

Tender menurut Fahmi (2009) mempunyai pengertian tawaran mengajukan harga untuk memborong suatu pekerjaan, untuk mengadakan barang-barang atau untuk menyediakan jasa. Tawaran dilakukan oleh pemilik kegiatan atau proyek. Demi alasan efektivitas dan efisiensi proyek dilaksanakan sendiri maka lebih baik diserahkan kepada pihak lain yang mempunyai kapabilitas melaksanakan proyek atau kegiatan. Transaksi dalam rangka penawaran tender dapat dilakukan baik di dalam maupun di luar bursa efek. Transaksi di luar bursa efek adalah transaksi yang dilaksanakan antara pembeli dan penjual secara langsung.

\section{Fuzzy Analytic Hierarchy Process}

Fuzzy Analytic Hierarchy Process (FAHP) adalah sebuah pendekatan yang dikembangkan pada akhir tahun 1970 sebagai struktur suatu penelitian dan pembuat suatu keputusan yang didefinisikan ke dalam metodologi berbasis prinsip matematis dan menggunakan pendekatan fuzzy (Bhushan dan Kanwal, 2005). FAHP menutupi kelemahan yang terdapat pada AHP, yaitu permasalahan terhadap kriteria yang memiliki sifat subjektif lebih banyak. Untuk menangani ketidakpresisian ini diajukan dengan menggunakan teori fuzzy set.
Ketidakpastian bilangan direpresentasikan dengan urutan skala. Untuk menentukan derajat keanggotaan pada FAHP, digunakan aturan fungsi dalam bentuk bilangan fuzzy segitiga atau Triangular Fuzzy Number (TFN) yang disusun berdasarkan himpunan linguistik. Jadi, bilangan pada tingkat intensitas kepentingan pada AHP ditransformasikan ke dalam himpunan skala TFN. TFN digunakan untuk proses fuzzyfikasi dari matriks perbandingan yang bersifat crisp. Data yang kabur akan direpresentasikan dalam TFN. Setiap fungsi keanggotaan didefinisikan dalam 3 parameter, yakni $1, \mathrm{~m}$, dan u. Dimana 1 adalah nilai kemungkinan terendah, $\mathrm{m}$ adalah nilai kemungkinan tengah, dan $u$ adalah nilai kemungkinan teratas pada interval putusan pengambil keputusan itu sendiri.

Berdasarkan struktur hierarki untuk membangun gedung dan mengukur desain alternatif yang dibangun oleh Hsieh, dkk. (2004) maka akan dilakukan implementasi terhadap framework tersebut. Model konseptual dapat digambarkan pada Gambar 2.

Penentuan Kriteria dan Sub-Kriteria Penelitian

Suatu penelitian pada dasarnya merupakan suatu upaya sistematis untuk menjelaskan masalah dengan cara memandang masalah tersebut sebagai hubungan antar kriteria. Berdasarkan penelitian sebelumnya yang dilakukan oleh Hsieh, dkk. (2004) terdapat 6 kriteria dan 20 sub-kriteria yang berfungsi sebagai framework dasar penelitian yang akan dilakukan. Penentuan kriteria penelitian ini dapat dilihat pada Tabel 1.

Masing-masing kriteria penelitian dibentuk dari beberapa sub-kriteria. Pada Tabel 2. ditampilkan sub-kriteria untuk setiap kriteria penelitian.

\section{Penentuan Model Kuesioner}

Kuesioner merupakan salah satu langkah untuk mendapatkan data dalam suatu penelitian. Pada penelitian ini kuesioner berfungsi untuk mencari bobot kriteria dan sub-kriteria yang diukur berdasarkan pendapat experts menggunakan kuesioner model tertutup. Pada kuesioner terdapat 4 bagian, yaitu :

- Bagian 1. Berisi data umum dari responden

- Bagian 2. Berisi petunjuk pengisian kuesioner bagi responden

- Bagian 3. Merupakan penilaian terhadap bobot antar kriteria building planning \& design altenatives assessment

- Bagian 4. Merupakan penilaian terhadap bobot antar sub-kriteria building planning \& design altenatives assessment.

\section{Pengolahan Hasil Kuesioner}

Pengolahan hasil kuesioner menggunakan tools Fuzzy Analytic Hierarchy Process (Fuzzy AHP). Langkah - langkah yang dilakukan dalam membuat 
dan menganalisis framework AHP adalah (Chang, 1996) :

1. Menghitung indeks konsistensi dan konsistensi rasio

2. Penyusunan Nilai Triangular Fuzzy Number (TFN) dari Hasil Perbandingan Berpasangan.

3. Penyusunan Matriks Triangular Fuzzy Number (TFN) Hasil Perbandingan Berpasangan campus sustainability
4. Perhitungan Local Weight kriteria dan subkriteria

\section{Hasil dan Pembahasan}

Output pengolahan data kriteria dan sub-kriteria penelitian dapat dilihat pada Tabel 3.

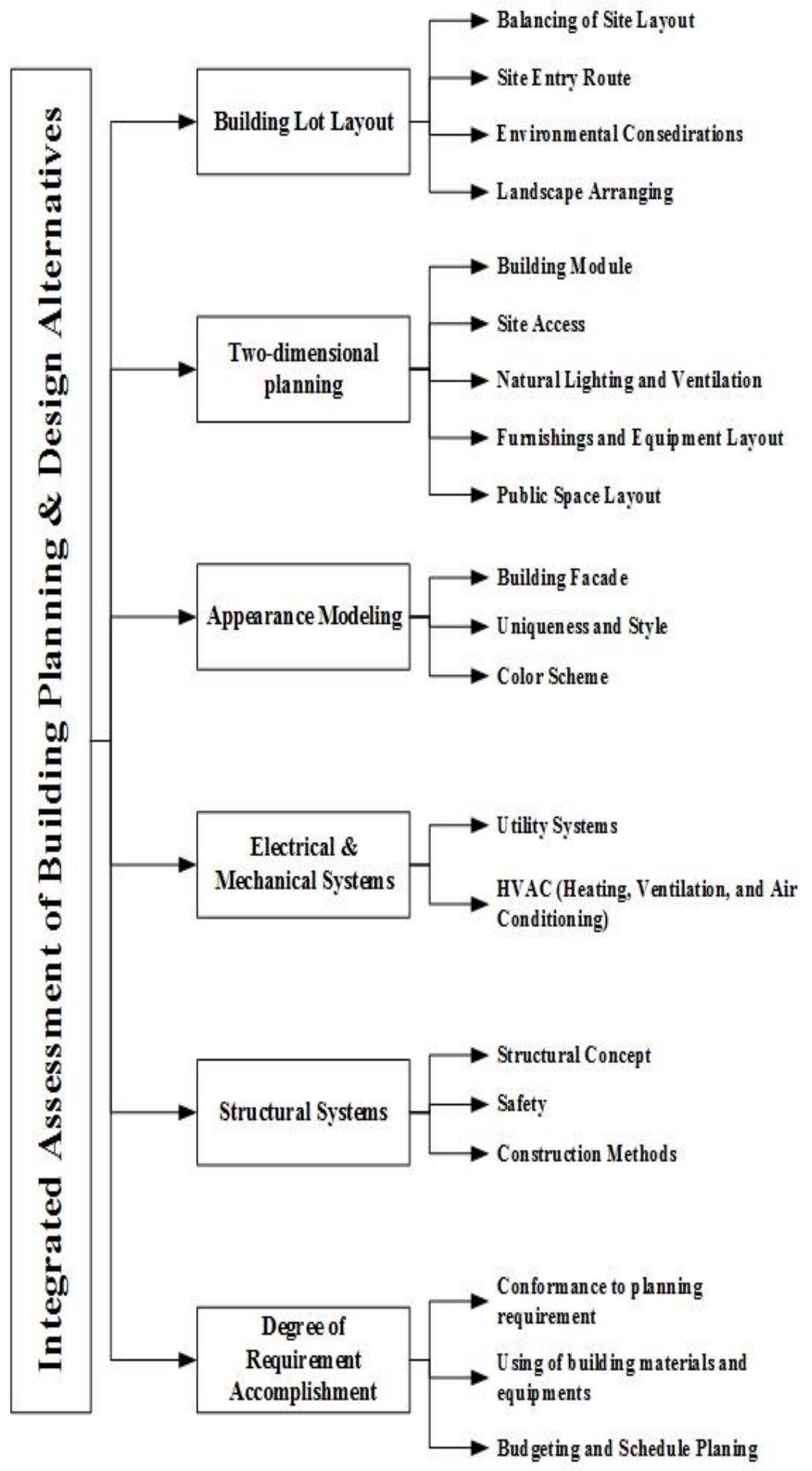

Gambar 2. Model Konseptual

(Sumber: Hsieh, dkk., 2004) 
Tabel 1. Kriteria dan Definisi Operasional

\begin{tabular}{|c|c|c|}
\hline Kriteria & Definisi & Sumber \\
\hline $\begin{array}{l}\text { Tata Letak } \\
\text { Bangunan }\end{array}$ & $\begin{array}{l}\text { Pembangunan konstruksi gedung dalam suatu daerah dengan } \\
\text { memperhatikan komunitas yang ada di sekitarnya seperti jalan dan saluran } \\
\text { tanah }\end{array}$ & Willcox, 2014 \\
\hline $\begin{array}{l}\text { Perencanaan } \\
\text { Dua } \\
\text { Dimensi }\end{array}$ & $\begin{array}{l}\text { Rencana pembangunan yang berisi penggambaran floor plans, place, serta } \\
\text { objek bangunan yang di gambar di atas kertas, baik secara horizontal } \\
\text { maupun vertikal }\end{array}$ & $\begin{array}{l}\text { Whitlock } \\
\text { A, } 1946\end{array}$ \\
\hline $\begin{array}{c}\text { Model } \\
\text { Penampilan }\end{array}$ & $\begin{array}{l}\text { Model yang menghasilkan penampilan bangunan yang dapat dilihat oleh } \\
\text { publik }\end{array}$ & Forrest, 2008 \\
\hline $\begin{array}{l}\text { Sistem } \\
\text { Elektrik dan } \\
\text { Mekanik }\end{array}$ & $\begin{array}{l}\text { Sistem elektrik dan mekanik dalam suatu bangunan yang dapat } \\
\text { menurunkan panas, mendinginkan, dan menerangkan ruangan atau } \\
\text { mengurangi konsumsi energi. }\end{array}$ & $\begin{array}{l}\text { Grondzik, dkk., } \\
\qquad 2010\end{array}$ \\
\hline $\begin{array}{l}\text { Sistem } \\
\text { Struktural }\end{array}$ & $\begin{array}{l}\text { Sistem yang menjadi dasar struktural bangunan yang menghubungkan } \\
\text { arsitektur bangunan guna membangun fungsi dari bangunan tersebut }\end{array}$ & $\begin{array}{l}\text { American Society } \\
\text { Civil Engineering, } \\
2013\end{array}$ \\
\hline $\begin{array}{l}\text { Tingkat } \\
\text { Persyaratan } \\
\text { yang } \\
\text { Terpenuhi }\end{array}$ & $\begin{array}{l}\text { Tingkat sejauh mana persyaratan proyek diraih seperti penggunaan } \\
\text { material, peralatan, biaya, dan rencana }\end{array}$ & $\begin{array}{l}\text { Hsieh. } \\
\text { Dkk, } \\
2004\end{array}$ \\
\hline
\end{tabular}

Tabel 2. Sub-kriteria dan Definisi Operasional

\begin{tabular}{|c|c|}
\hline Kriteria & Sub-kriteria \\
\hline \multirow{4}{*}{ Tata Letak Bangunan } & Keseimbangan tata letak \\
\hline & Rute masuk bangunan \\
\hline & Kebutuhan lingkungan \\
\hline & Pengaturan pemandangan \\
\hline \multirow{5}{*}{ Perencanaan Dua Dimensi } & Modul bangunan \\
\hline & Akses bangunan \\
\hline & Pencahayaan Natural dan Ventilasi \\
\hline & Tata Letak Perabotan dan Peralatan \\
\hline & Tata letak ruang publik \\
\hline \multirow{3}{*}{ Model Penampilan } & Tampilan muka \\
\hline & Keunikan dan Gaya \\
\hline & Pemilihan warna \\
\hline \multirow{2}{*}{$\begin{array}{c}\text { Sistem Elektrik dan } \\
\text { Mekanik }\end{array}$} & Sistem utilitas \\
\hline & Hvac \\
\hline \multirow{3}{*}{ Sistem Struktural } & Konsep struktural \\
\hline & Keamanan \\
\hline & Metode konstruksi \\
\hline \multirow{3}{*}{$\begin{array}{c}\text { Tingkat Persyaratan yang } \\
\text { Terpenuhi }\end{array}$} & Kesesuaian dengan Persyaratan Proyek \\
\hline & Penggunaan Material dan Peralatan \\
\hline & Biaya dan Rencana Waktu Proyek \\
\hline
\end{tabular}


Tabel 3. Output Penelitian

Kriteria

Local weight
Sub kriteria
Local weight Global weight

\begin{tabular}{|c|c|c|c|c|}
\hline \multirow{4}{*}{ Tata letak bangunan } & \multirow{4}{*}{0,140} & Keseimbangan tata letak & 0,241 & 0,034 \\
\hline & & Rute masuk bangunan & 0,240 & 0,034 \\
\hline & & Pertimbangan lingkungan & 0,278 & 0,039 \\
\hline & & Pengaturan pemandangan & 0,241 & 0,034 \\
\hline \multirow{5}{*}{ Perencanaan dua dimensi } & \multirow{5}{*}{0,156} & Modul bangunan & 0,210 & 0,033 \\
\hline & & Akses bangunan & 0,194 & 0,030 \\
\hline & & Pencahayaan natural dan ventilasi & 0,209 & 0,033 \\
\hline & & Tata letak perabotan dan peralatan & 0,194 & 0,030 \\
\hline & & Tata letak ruang publik & 0,193 & 0,030 \\
\hline \multirow{3}{*}{ Model penampilan } & \multirow{3}{*}{0,163} & Tampilan muka bangunan & 0,341 & 0,056 \\
\hline & & Keunikan dan gaya bangunan & 0,312 & 0,051 \\
\hline & & Pemilihan warna & 0,348 & 0,057 \\
\hline \multirow{2}{*}{$\begin{array}{c}\text { Sistem elektrik dan } \\
\text { mekanik }\end{array}$} & \multirow{2}{*}{0,173} & Sistem utilitas & 0,585 & 0,101 \\
\hline & & Hvac & 0,415 & 0,072 \\
\hline \multirow{3}{*}{ Sistem struktural } & \multirow{3}{*}{0,197} & Konsep struktural & 0,371 & 0,073 \\
\hline & & Keamanan bangunan & 0,287 & 0,057 \\
\hline & & Metode konstruksi & 0,342 & 0,067 \\
\hline \multirow{3}{*}{$\begin{array}{c}\text { Tingkat persyaratan yang } \\
\text { terpenuhi }\end{array}$} & \multirow{3}{*}{0,172} & Kesesuaian dengan persyaratan proyek & 0,290 & 0,050 \\
\hline & & Penggunaan material & 0,342 & 0,059 \\
\hline & & Biaya dan perencanaan durasi proyek & 0,367 & 0,063 \\
\hline
\end{tabular}

Dalam Merit Point System yang diatur dalam keputusan direksi PT. Asuransi ASEI Indonesia masing-masing ada beberapa kekurangan baik menurut peneliti maupun menurut Pejabat Pelaksana Pengadaan Barang dan Jasa (PPBJ) di PT. Asuransi ASEI Indonesia. Kekurangan Merit Point System yang dilakukan oleh PT Asuransi ASEI Indonesia menurut peneliti adalah setiap kriteria tidak memiliki sub-kriteria untuk mengukurnya. Sedangkan kekurangan Merit Point System menurut Pejabat Pelaksana Pengadaan Barang dan Jasa (PPBJ) PT. Asuransi ASEI Indonesia berdasarkan hasil wawancara adalah tidak adanya aturan yang mengatur mengenai pembagian bobot masingmasing kriteria. Hal ini sangat fatal, karena dapat menimbulkan peluang untuk melakukan tindakan yang melanggar hukum serta penunjukan penyedia yang kurang berkualitas. Sehingga untuk menyelesaikan masalah tersebut, digunakanlah tools Fuzzy AHP untuk mendapatkan bobot masingmasing kriteria penilaian dalam mekanisme Merit Point System.

Dari hasil pengolahan data menggunakan 6 (enam) kriteria penelitian untuk memilih penyedia jasa konstruksi pembangunan gedung di PT Asuransi Ekspor Indonesia menggunakan mekanisme merit point system, kriteria sistem struktural yang dianggap oleh Pejabat Pelaksana Pengadaan Barang dan Jasa (PPBJ) PT. Asuransi ASEI Indonesia paling penting. Hal ini dibuktikan dengan output penelitian yang menunjukkan bahwa kriteria sistem struktural memiliki bobot terbesar di antara kriteria lain sebesar 0,197 atau 19,7\%. Sistem struktural sendiri termasuk diantaranya sub-kriteria konsep struktural, keamanan bangunan, dan metode konstruksi.

Pentingnya sistem struktural menurut hasil pengolahan data yang diisi oleh Pejabat Pelaksana Pengadaan Barang dan Jasa (PPBJ) PT. Asuransi ASEI Indonesia juga didukung secara teori yang mengatakan bahwa sistem struktural adalah kriteria yang penting. Menurut Sulardi (2013), perencanaan struktur suatu gedung bertingkat secara rinci membutuhkan suatu rangkaian proses analisis dan perhitungan yang panjang serta rumit, yang didasarkan pada asumsi dan pertimbangan teknis tertentu. Dengan kecanggihan perangkat lunak yang ada pada saat ini memungkinkan para teknisi untuk merencanakan segala sesuatunya dari berbagai sudut pandang dengan sangat rinci dengan tingkat ketelitian yang tinggi. Namun seringkali para perencana mengikuti secara penuh hasil keluaran suatu komputer tanpa mengkaji ulang apakah hasil keluaran tersebut mengandung berbagai 
kejanggalan. Kadangkala kejanggalan tersebut tidak mudah ditemukan karena para perencana belum atau kurang memiliki kepekaan terhadap perilaku struktur yang direncanakan.

Kejanggalan ini yang nantinya akan dapat menyebabkan potensi kerusakan bahkan keruntuhan gedung baik selama proses konstruksi maupun saat kegiatan operasional di dalam gedung berlangsung. Beberapa contoh gedung yang rusak atau runtuh akibat penyedia yang kurang memahami sistem struktural adalah gedung Skyline Plaza - Bailey's Cross roads pada tahun 1973 yang tidak memperhatikan penyebaran beban ke lantai bawah saat pembongkaran bekisting. Lalu gedung David L. Lawrence Convention Centre pada tahun 1990 yang runtuh akibat perubahan penopang rangka baja yang semula didesain penopang tekan menjadi penopang tarik. Lalu gedung Harbour Cay Condominium pada tahun 1981 yang runtuh akibat kesalahan design dan konstruksi. Contoh di atas adalah kesalahan yang dapat terjadi akibat penyedia yang tidak memahami secara betul sistem struktural.

Maka dari itu, menurut Pejabat Pelaksana Pengadaan Barang dan Jasa (PPBJ) PT. Asuransi ASEI Indonesia, penyedia yang baik adalah penyedia yang memahami betul lingkup pekerjaan struktural yang akan dikerjakan. Sehingga diharapkan saat proyek berjalan nantinya tidak ada hambatan yang berarti, apalagi sampai penyedia berhenti mengerjakan proyek karena terhambat kendala, atau gedung yang dikerjakan mengalami kerusakaan sebelum atau saat kegiatan operasional perusahaan berjalan. Hal ini tentu sangat merugikan perusahaan karena dapat menyebabkan molornya waktu pengerjaan proyek yang berdampak kerugian bagi PT. Asuransi ASEI Indonesia baik dalam segi biaya maupun waktu, karena kegiatan operasional perusahaan pun harus tertunda.

PT. Asuransi ASEI Indonesia tidak ingin membangun gedung yang hanya mementingkan kuantitas atau dalam hal ini adalah waktu, tanpa memperhatikan kualitas atau dalam hal ini salah satunya adalah tingkat keamanan bangunan. Karena PT. Asuransi ASEI ingin membangun gedung sebagai investasi jangka panjang. Maka ketika bangunan sudah mengalami kerusakan bahkan jauh sebelum prediksi kerusakan bangunan, hal itu akan merugikan PT. Asuransi ASEI Indonesia. Menanggapi hal tersebut, Pejabat Pelaksana Pengadaan Barang dan Jasa (PPBJ) PT. Asuransi ASEI Indonesia tidak langsung tergiur dengan penyedia yang menjanjikan pembangunan gedung yang lebih cepat. Karena menurut hasil penelitian, Pejabat Pelaksana Pengadaan Barang dan Jasa (PPBJ) PT. Asuransi ASEI Indonesia lebih memprioritaskan penyedia yang memahami betul sistem struktural dalam membangun gedung.

Keamanan merupakan modal dasar berdirinya suatu bangunan, karena apabila bangunan mengalami kerusakan nantinya akan berdampak fatal baik itu kerugian secara material maupun yang terberat adalah korban jiwa. Maka dari itu berdasarkan hasil pengolahan data penelitian, sistem struktural adalah kriteria terpenting dengan bobot terbesar berdasarkan pendapat Pejabat Pelaksana Pengadaan Barang dan Jasa (PPBJ) di PT. Asuransi ASEI Indonesia.

\section{Kesimpulan}

Kesimpulan dari penelitian yang dilakukan oleh peneliti di PT. Asuransi ASEI Indonesia adalah sebagai berikut :

1. Peneliti menggunakan framework penelitian yang pernah dilakukan sebelumnya oleh Hsieh, dkk (2004) yang berjudul Fuzzy MCDM Approach for Planning and Design Tenders Selection in Public Office Buildings untuk memilih penyedia dengan sistem build \& design di PT.. Asuransi ASEI Indonesia. Penelitian menggunakan enam kriteria yang terdiri dari tata letak bangunan, perencanaan dua dimensi, model penampilan, sistem elektrik dan mekanik, sistem struktural, dan tingkat persyaratan yang terpenuhi. Penelitian juga menggunakan dua puluh sub-kriteria untuk mengukur kriteria.

2. Kriteria yang memiliki bobot terbesar menurut hasil pengolahan data adalah kriteria sistem struktural. Lalu diikuti oleh kriteria sistem elektrik dan mekanik dan kriteria tingkat persyaratan yang dipenuhi dengan bobot yang hampir sama. Lalu di bawahnya ada kriteria model penampilan diikuti kriteria perencanaan dua dimensi dan terakhir kriteria dengan bobot terendah adalah kriteria tata letak bangunan. Keseluruhan bobot kriteria akan dipakai dalam menentukan penyedia di PT. Asuransi ASEI Indonesia menggunakan mekanisme merit point system.

\section{Daftar Pustaka}

American Society of Civil Engineering (ASCE). 2013. Structural Systems to Build A Better Community. ASCE Charles Pankow Foundation Architectural Engineering Student Competition. Pankow

Bhushan N dan Kanwal R. 2005. Strategic Decision Making Applying the Analytic Hierarchy Process. Decision Engineering. Bedford

Chang. 1996. Applications of The Extent Analysis Method on Fuzzy AHP. European Journal of Operational Research.

Departement of Trade and Industry (DTI). 2003. Public Procurement : A Toolkit for Social Enterprises. UK Government. Amerika

Fahmi.A, dkk. 2009. Hukum Persaingan Usaha Indonesia. Deutsche Gesellschaft fur Technische Zusammenarbeit (GTZ) Gmbh. Indonesia

Forrest, 2008. Village of Deerfield Appearance Code. Ad Hoc Comittee on Appearance Code. Scotland 
Grondzik, dkk. 2010. Mechanical and Electrical Equipment for Buildings. Willey: Eleventh Edition. New York

Hsieh, dkk. 2004. Fuzzy MCDM Approach for Planning and Design Tenders Selection in Public Office Buildings. International Journal of Project Management Vol 22.

Sulardi. 2013. Perencanaan Struktur Bangunan Tinggi. Universitas Gunadarma. Jakarta

Whitlock. A. 1946. A62 Guide for Modular Coordination : A Guide to Assist Architects and Engineers in Applying Modular Coordination to Building Plans and Details. Modular Service Association. English

Willcox. 2014. Building Layout. Goodheart-Willcox Publisher. Inggris 